\title{
PREVALENCE AND ANTIMICROBIAL RESISTANCE ASSESSMENT OF SUBCLINICAL MASTITIS IN MILK SAMPLES FROM SELECTED DAIRY FARMS
}

\author{
${ }^{1,3}$ Murugaiyah Marimuthu, ${ }^{1,3}$ Faez Firdaus Jesse Abdullah, \\ ${ }^{1,4}$ Konto Mohammed, ${ }^{1}$ Sangeetha D/O Sarvananthan Poshpum, \\ ${ }^{1,4}$ Lawan Adamu, ${ }^{1,2}$ Abdinasir Yusuf Osman, ${ }^{2,4}$ Yusuf Abba and ${ }^{2,4}$ Abdulnasir Tijjani \\ ${ }^{1}$ Department of Veterinary Clinical Studies, \\ ${ }^{2}$ Department of Veterinary Pathology and Microbiology, \\ ${ }^{3}$ Research Centre for Ruminant Disease, \\ Faculty of Veterinary Medicine, Universiti Putra Malaysia, 43400 UPM Serdang, Selangor, Malaysia \\ ${ }^{4}$ Faculty of Veterinary Medicine, University of Maiduguri, PMB 1069, Borno State, Nigeria
}

Received 2014-01-22; Revised 2014-02-02; Accepted 2014-03-12

\begin{abstract}
This study was conducted in order to determine the prevalence and bacteriological assessment of subclinical mastitis and antimicrobial resistance of bacterial isolates from dairy cows in different farms around Selangor, Malaysia. A total of 120 milk samples from 3 different farms were randomly collected and tested for subclinical mastitis using California Mastitis Test (CMT), as well as for bacterial culture for isolation, identification and antimicrobial resistance. The most prevalent bacteria was Staphylococcus sp. (55\%), followed by Bacillus sp., (21\%) and Corynebacterium sp., (7\%), Yersinia sp. and Neisseria sp. both showed 5\% prevalence, other species with prevalence below 5\% are Acinetobacter sp., Actinobacillus sp., Vibrio sp., Pseudomonas sp., E.coli, Klebsiella sp. and Chromobacter sp. Selected Staphylococcus sp. showed a mean antimicrobial resistance of $73.3 \%$ to Ampicillin, $26.7 \%$ to Penicillin, Methicillin and Compound Sulphonamide each, $20 \%$ to Oxacillin, Amoxycillin and Cefuroxime, $13.3 \%$ to Polymyxin B, Erythromycin, Ceftriaxone and Azithromycin and $6.7 \%$ to Streptomycin, Clindamycin, Lincomycin and Tetracycline each. This study indicates the need for urgent and effective control measures to tackle the increase in prevalence of subclinical mastitis and their antimicrobial resistance in the study area.
\end{abstract}

Keywords: Prevalence, Antimicrobial Resistance, Subclinical Mastitis, Milk Samples, Dairy Farms

\section{INTRODUCTION}

Milk, is an essential nutritious diet to young mammals containing proteins, lipids, amino acids, vitamins, minerals and carbohydrates. Milk also serves as an optimum medium for the propagation of various pathogenic and spoilage microorganisms (Minst et al., 2012; Gatti et al., 2013). These pathogens invade the mammary glands, develop and multiply, producing some toxic substances that results in inflammation, reduced milk production and altered milk quality, leading to a clinical condition known as mastitis (Oliver and Muranda, 2012; Rall et al., 2013). The most common bacterial pathogens responsible for clinical or subclinical mastitis in animals can be divided into two broad categories: Namely the contagious pathogens (Streptococcus agalactiae, Staphylococcus aureus and Mycoplasma species) and environmental or coliforms pathogens which include Escherichia coli and Klebsiella species, usually found around the dairy farm (Hogan et al., 2011; Oliver and Muranda, 2012; Rall et al., 2013). Apart from these, several other pathogens such as Lactobacillus, Universiti Putra Malaysia, 43400 UPM Serdang, Selangor, Malaysia 
Salmonella, Listeria, Pseudomonas, Corynebacterium, Campylobacter and Micrococcus species have also been reported in raw milk worldwide (Waller et al., 2011; Hill et al., 2012; Santman-Berends et al., 2012; Bracke et al., 2013). Subclinical mastitis is the most common form of mastitis among dairy cattle (Salvador et al., 2012), with a prevalence of about 40-50 times more than the clinical mastitis (Roy et al., 2009; Mekibib et al., 2010); which attracts for prompt attention in the dairy industry. However, the prevalence was reported to be influenced by factors such as breed, anatomical abnormality of the udder, stage of lactation, parity and management practice (Almaw et al., 2008).

Antimicrobial resistance of mastitis pathogens to multiple drugs has been reported worldwide (Waller et al., 2011; Oliver and Muranda, 2012; Chaudhary and Payasi, 2013). This is because of indiscriminate use of the antibiotics by farmers, thereby rendering them ineffective and leading to permanent loss of the mammary tissues. The pathogens can transfer the resistance to a sensitive bacterium by conjugation known as R-plasmid mediated antibiotic resistance (Ahmad et al., 2001). The prevalence of antibiotic resistance usually varies between isolates from different samples and even between herds in the same farm (Chaudhary and Payasi, 2013; Rall et al., 2013). Since antibiotics play an important role in the control of mastitis, a sound surveillance system for antibiotic resistance that will ensure optimal result and minimize the risk of development and spread of resistance in dairy farms is very crucial. Thus, the aim of this study was to assess the bacteriology and determine the antimicrobial resistance from subclinical mastitis in milk samples from selected dairy farms in Selangor Malaysia.

\section{MATERIALS AND METHOD}

\subsection{Sample Collection}

A total of 120 raw milk samples were collected from 3 different farms around Selangor. Ten animals were selected randomly from each farm and 4 different samples were taken from each animal (one sample from each udder). The general udder health and appearance were first examined for any abnormalities. The udder was thoroughly washed with clean water and wiped dry. The teats were then disinfected with alcohol. About $5 \mathrm{ml}$ of raw milk was aseptically stripped separately into sterile universal bottle according to the quarters after discarding the first two stripping. The samples were then kept in ice at $4^{\circ} \mathrm{C}$ for further analysis.

\subsection{Farms and Cows Selection Criteria}

Farms with no history of clinical mastitis or mastitis causing pathogens are targeted and the farm inclusion criteria are (1) being a dairy farm (2) herd size must have more than 20 lactating cows and (3) no history of recent antibiotic therapy.

Cow inclusion criteria to be included in the study, a cow must be (1) healthy with no concurrent disease requiring treatment (2) no teat lesions (3) no clinical mastitis (4) no recent treatment against mastitis or with an anti-inflammatory drugs.

\subsection{Laboratory Analysis}

Bacteriological culture and identification were carried out according to National Mastitis Council Standards.

\subsection{Antibiotic Resistance Test}

Confirmed prevalent bacterial isolates were subjected to the standard Kirby Bauer method to determine their susceptibility against 15 antimicrobial agents. Five pure culture isolates of Staphylococcus species were selected randomly from each farm and suspended into $2 \mathrm{~mL}$ of nutrient broth and standardized to $0.5 \mathrm{Mc}$ Farland Standard. The inoculums were then swabbed over a Mueller Hinton $(\mathrm{MH})$ agar surfaces and plates were examined for zone of inhibition and resistance. Using a calliper, the diameter zone of inhibition was carefully measured to nearest millimetre where only the clear area was taken as zone of complete inhibition of growth determined by the naked eye. Results were interpreted using Clinical and Laboratory Standards Institute (CLSI) tables (M100-21), 2008.

\subsection{Statistical Analysis}

Prevalence of mastitis using SCC as indices in the 3 farms was compared between groups using analysis of variance. The statistical analyses were carried out using SPSS Statistical Software Version 20.1 and statistical significance was defined as $\mathrm{p}<0.05$.

\section{RESULTS}

The figure above clearly showed that the prevalence of subclinical mastitis in dairy cows is high in these study areas and there is a significant difference $(\mathrm{p}<0.05)$ among the farms with a minimum of $70 \%$ and a maximum of $100 \%$ prevalence in all the farms visited (Fig. 1). 
Bacterial identification from all the 3 farms above revealed Staphylococcus sp., as the most prevalent bacteria followed by Bacillus sp. and Corynebacterium $s p$. as the first 3 most prevalent bacterial pathogens in the study area with a prevalence of 55,21 and $7 \%$, respectively. Yersinia sp and Niesseria sp.showed 5\% prevalence each, Vibrio 4\% and Acinetobacter spp. 3\%; Actinobacillus spp., Pseudomonas spp., E. coli and Chromobacter spp. all showed a prevalence of $1 \%$ each, while Klebsiella spp. Showed $0.01 \%$ prevalence (Fig. 2).
Antimicrobial sensitivity tests conducted on Staphylococcus spp. being the most prevalent bacteria revealed an average resistance of $73.3 \%$ to Ampicillin, $26.7 \%$ to Penicillin, Methicillin and compound Sulphonamide, $20 \%$ to Oxacillin, Amoxycillin and Cefuroxime, $13.3 \%$ Polymyxin B, Erythromycin, Ceftriaxone and Azithromycin,and lastly $6.7 \%$ to Streptomycin, Clindamycin Lincomycin and Tetracycline each (Fig. 3).

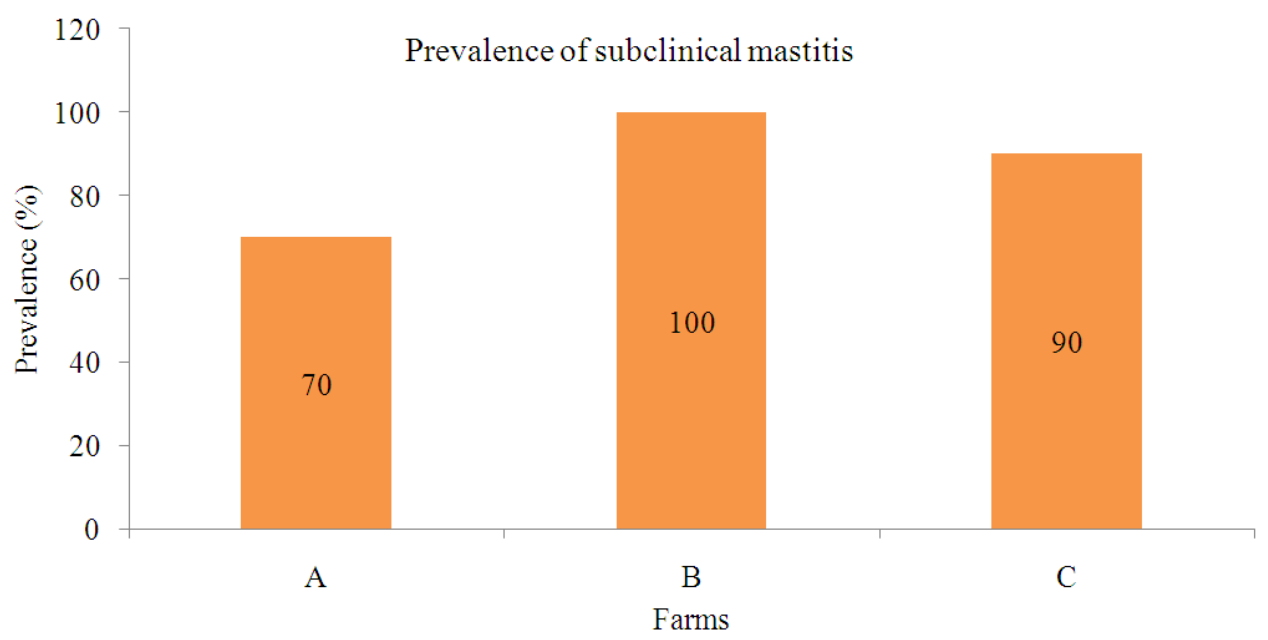

Fig. 1. Shows the Prevalence of Subclinical Mastitis in three farms around Selangor, using California Mastitis Test (whereby an animal is considered mastitis positive when one of its quarters is infected), $\mathrm{N}=30, \mathrm{~S} . \mathrm{E}=8.82, \alpha=0.05$, A (C.I = 53.6, 86.4); B (C.I = 100, 100); C (C.I = 79.2, 100.7 $) \mathrm{N}=$ Population size; S.E = Standard error; C.I = Confidence interval; $\alpha=p$-value, A, B and C = Farms

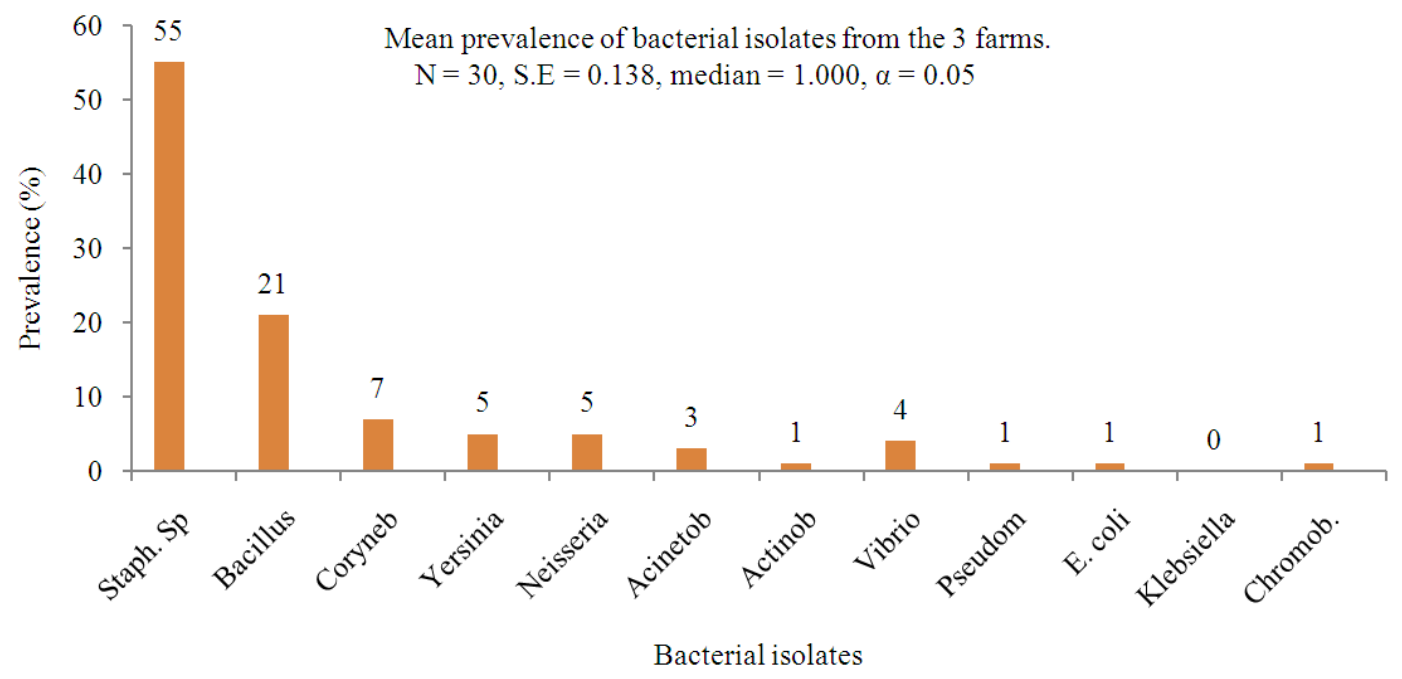

Fig. 2. Shows the mean prevalence of the different bacterial isolates from the 3 farms, NB: The horizontal axis represents $\rightarrow: 55=$ Staphylococcus sp., $21=$ Bacillus sp., $7=$ Corynebacterium sp., $5=$ Yersinia $s p ., 5=$ Neisseria, $3=$ Acinetobacter, $1=$ Actinobactersp, $4=$ Vibrio $s p, 1=$ Pseudomonas sp., $1=$ E. coli, $0=$ Klebsiella, $1=$ Chromobacter $s p$ 


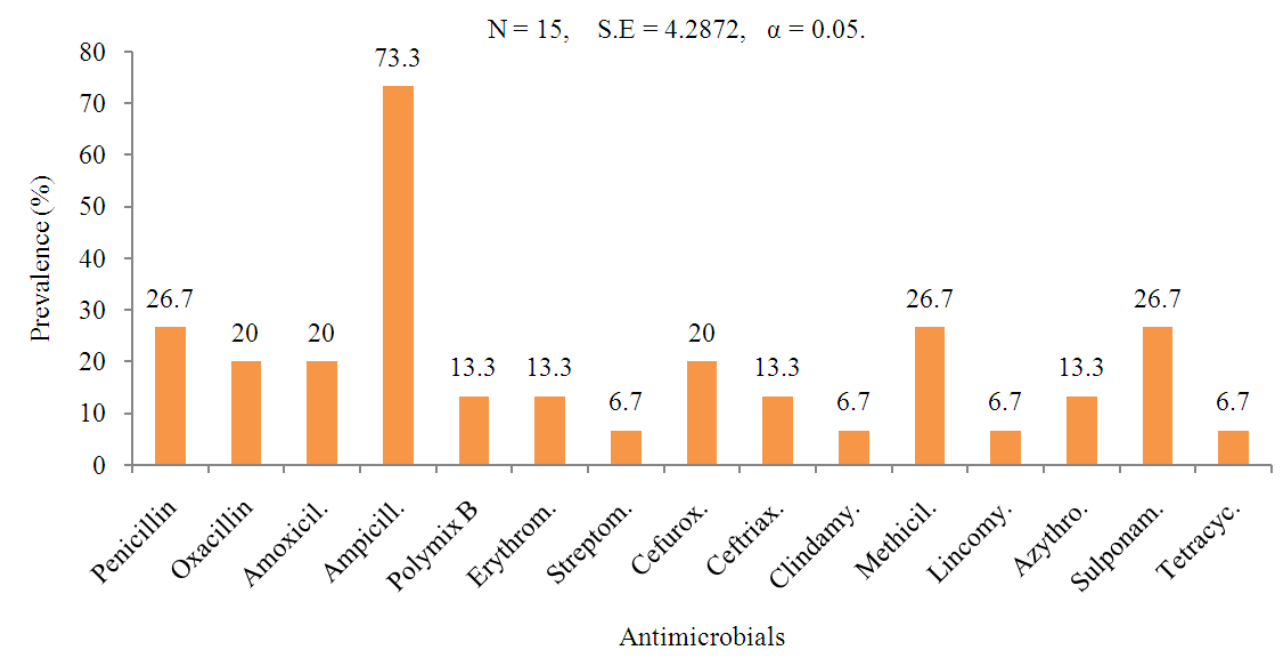

Fig. 3. Shows the antimicrobial resistance of Staphylococcus spp. to different types of antimicrobial agents, NB: The horizontal axis represents $\rightarrow: 55=$ Staphylococcus sp., $21=$ Bacillus sp., $7=$ Corynebacterium $s p ., 5=$ Yersinia sp, $5=$ Neisseria, $3=$ Acinetobacter, $1=$ Actinobactersp, $4=$ Vibrio sp, $1=$ Pseudomonas $\mathrm{sp} ., 1=$ E. coli, $0=$ Klebsiella, $1=$ Chromobacter $s p$

\section{DISCUSSION}

The high prevalence of subclinical mastitis in the study areas as seen in this study agrees with an earlier report by Chye et al. (2004) who suggested that the high prevalence of subclinical mastitis in Malaysia was possibly as a result of unhygienic milking practices in the milking parlor, contaminated equipments and/ or contaminated water used for cleaning utensil and the animals as well as milk storage condition. This phenomenon also applies to the varied differences amongst the different farms seen in this study.

The predominance of Staphylococcus $s p$ as the most prevalent bacteria in subclinical mastitis also corresponds to the report by Rall et al. (2013); who reported that beside other minor pathogens, Staphylococcus aureus was still the most prevalent pathogen in clinically healthy animals. It has also been described in humans as the major cause of nosocomial and community acquired infections (Chaudhary and Payasi, 2013). Most of the organisms isolated from this study have also been reported as either contagious or environmental pathogens that are found in raw milk from different parts of the world (Waller et al., 2011; Hogan et al., 2011; Santman-Berends et al., 2012; Hill et al., 2012; Oliver and Muranda, 2012; Chaudhary and Payasi, 2013). Staphylococcus and Corynebacterium species are considered before as minor pathogens found in milk; but, have now became more common as mastitis causing organisms (Oliver and Muranda, 2012).
The presence of some bacteria in milk is an indication of contamination, a classical example of such bacterium is $E$. coli which is commonly found in manure, soil and contaminated water. Inappropriate human practice like poor personal hygiene can lead to contamination of water by human waste products (Chaudhary and Payasi, 2013; Hassan and Alkafagi, 2013). Pseudomonas sp. usually found in soil also contaminates water bodies and are also considered as an important bacterial contaminant found in raw milk. Thus, they can gain access in milk via manure, polluted water, dairy equipment, dairy workers and flies, causing severe public health threat to consumers (Hassan and Alkafagi, 2013).

Antimicrobial sensitivity tests of Staphylococcus aureus as seen in this study agrees with earlier reports by Kalmus et al. (2011), who reported a heightened resistance of Staphylococcus aureus to Penicillin and Ampicillin. There is no scientific evidence as to the resistance pattern of mastitis pathogens to penicillin and the Cephalosporin group, but there were widespread reports of antimicrobial drug resistance among Staphylococcus pathogens for over 2-3 decades as earlier reported by Kalmus et al. (2011) in Estonia, Botrel et al. (2010) in Germany; Persson et al., 2011 in Sweden Sahebekhtiari et al. (2011) in Iran, Chaudhary and Payasi, 2013 in India and Rall et al. (2013) in Brazil. The trend of resistance patterns to antibiotic use over time showed a long-term effect of over 3-7 years (Rall et al., 2013). Another way of assessing the effects of 
antimicrobial use on antimicrobial resistance is to compare the different systems of production, such as comparing those dairies that use little to no antimicrobials and those that use antimicrobials in all categories of animals in the farm.

\section{CONCLUSION}

Prevalence of subclinical mastitis is high in the selected farms around Selangor and antibiotic resistance patterns does not show widespread emerging resistance among mastitis pathogens to antibacterial drugs even though many of these antibiotics have been used in the dairy industry for treatment and prevention of disease for several decades. However, it is clear that the use of antibiotics in dairy cows can contribute to increased antimicrobial resistance. Therefore, it is recommended that training and guidance should be given to farmers and animal handlers, as some of the bacterial pathogens found are of human source.

\section{ACKNOWLEDGEMENT}

The researchers would like to acknowledge the efforts of the entire staff of the Large Animal Ward of the University Veterinary Hospital and bacteriology Laboratory for their support and the farms owners for their willingness and cooperation during the course of this research.

\section{REFERENCES}

Almaw, G., A. Zerihun and Y. Asfaw, 2008. Bovine mastitis and its association with selected risk factors in smallholder dairy farms in and around Bahir Dar, Ethiopia. Tropical Animal Health Production, 40: 427-432. DOI: 10.1007/s11250007-9115-0

Ahmad, Q.R., R.C. Allen, T.C. Andersen and J.D. Anglin, 2001. Measurement of the Rate of $v$ e+ $d \rightarrow$ $p+p+e$-interactions produced by B 8 solar neutrinos at the Sudbury neutrino observatory. Phys. Rev. Lett., 87: 071301-071301. DOI: 10.1103/PhysRevLett.87.071301

Botrel, M.A., M. Haenni and E. Morignat, 2010. Distribution and antimicrobial resistance of clinical and subclinical mastitis pathogens in dairy cows in Rhône-Alpes, France. Foodborne Pathog Dis., 7: 479-487. DOI: 10.1089/fpd.2009.0425
Bracke, N., M. Van Poucke, B. Baert, E. Wynendaele and L. De Bels et al., 2013. Identification of a microscopically selected microorganism in milk samples. J. Dairy Sci., 97: 609-615. DOI: 10.3168/jds.2013-6932

Chaudhary, M. and A. Payasi, 2013. Prevalence of heterogeneous glycopeptide intermediate resistance in methicillin-resistant Staphylococcus aureus. Am. J. Infect. Dis., 9: 63-70. DOI: 10.3844/ajidsp.2013.63.70

Chye, F.Y., A. Abdullah and M.K. Ayob, 2004. Bacteriological quality and safety of raw milk in Malaysia. Food Microbiol., 21: 535-541. DOI: 10.1016/j.fm.2003.11.007

Gatti, M., B. Bottari, C. Lazzi, E. Neviani and G. Mucchetti, 2013. Invited review: Microbial evolution in raw-milk, long-ripened cheeses produced using undefined natural whey starters. J. Dairy Sci., 97: 573-591. DOI: 10.3168/jds.20137187

Hassan, H.F. and M. Alkafagi, 2013. Association of Escherichia coli with the prevalence of flies population. Am. J. Agric. Biol. Sci., 8: 217-221. DOI: 10.3844/ajabssp.2013.217.221

Hill, B., B. Smythe, D. Lindsday and J. Shepherd, 2012. Microbiology of raw milk in New Zealand. Int. J. Food Microbiol., 157: 305-308. DOI: 10.1016/j.ijfoodmicro.2012.03.031

Hogan, J.S., E. Berry and E. Hiller, 2011. Current Concepts of Bovine Mastitis. 5th Edn., Verona (WI): National Mastitis Council.

Kalmus, P., B. Aasmae and A. Karssin, 2011. Udder pathogens and their resistance to antimicrobial agents in dairy cows in Estonia. Acta Vet. Scand., 53: 4-4. DOI: 10.1186/1751-0147-53-4

Mekibib, B., M. Furgasa, F. Asunna, B. Megersa and A. Regassa, 2010. Bovine mastitis: Prevalence, risk factors and major pathogens in dairy farms of Holeta Town, central Ethiopia. Vet. World 3: 397-403. DOI: $10.5455 /$ vetworld.2010.397-403

Minst, K., E. Martibauer, T. Miller and C. Meyer, 2012. Short communication: Streptococcus species isolated from mastitis milk samples in Germany and their resistance to antimicrobial agents. J. Dairy Sci., 95: 6957-6962. DOI: 10.3168/jds.2012-5852

Oliver, S.P. and S.E. Muranda, 2012. Antibiotic resistance of mastitis pathogens. Vet. Clin. Food Anim., 28: 165-185. 
Persson, Y., A.K. Nyman and U. Gronlund-Andersson, 2011. Etiology and antimicrobial susceptibility of udder pathogens from cases of subclinical mastitis in dairy cows in Sweden. Acta Vet. Scand, 53: 36-36. DOI: 10.1186/1751-0147-53-36

Roy, B.C., N. Kakinuma and R. Kiyama, 2009. Kank attenuates actin remodeling by preventing interaction between IRSp53 and Rac1. J. Cell Biol., 184: 253-267. DOI: 10.1083/jcb.200805147

Rall, V.L.M., E.S. Miranda, I.G. Castilho and C.H. Camargo, 2013. Diversity of Staphylococcus species and prevalence of enterotoxin genes isolated from milk of healthy cows and cows with subclinical mastitis. J. Dairy Sci., 97: 829-837. DOI: 10.3168/jds.2013-7226

Salvador, R.T., J.M.C. Beltran, N.S. Abes, C.A. Gutierrez and C.N. Mingala, 2012. Short communication: Prevalence and risk factors of subclinical mastitis as determined by the California Mastitis Test in water buffaloes (Bubalis bubalis) in Nueva Ecija, Philippines. J. Dairy Sci., 95: 13631366. DOI: $10.3168 /$ jds.2011-4503
Santman-Berends, I.M.G.A., R.G.M. Olde-Riekerink, O.C. Sampimon, G. van Scaik and T.J.G.M. Lam, 2012. Incidence of subclinical mastitis in Dutch dairy heifers in the first 100 days in lactation and associated risk factors. J. Dairy Sci., 95: 24762484. DOI: $10.3168 /$ jds.2011-4766

Sahebekhtiari, N., Z. Nochi and M.A. Eslampour, 2011. Characterization of Staphylococcus aureus strains isolated from raw milk of bovine subclinical mastitis in Tehran and Mashhad. Acta Microbiol. Immunol. Hung., 58: 113-121. DOI: 10.1556/AMicr.58.2011.2.4

Waller, K.P., A. Aspan, A. Nyman, Y. Persson and A.U. Gronlund, 2011. CNS species and antimicrobial resistance in clinical and subclinical bovine mastitis. Vet. Micribiol., 152: 112-116. DOI: 10.1016/j.vetmic.2011.04.006 